\title{
Analisis Kualitas Perairan Bolaang Mongondow, Sulawesi Utara Berdasarkan Parameter Fisika-Kimia Air Laut
}

\author{
Simon I. Patty*, Fione Yukita Yalindua, Putri Sapira Ibrahim \\ Pusat Penelitian Oseanografi, Lembaga Ilmu Pengetahuan Indonesia \\ Jl. Pasir Putih No. 1. RT.8/RW.10, Pademangan Timur, Jakarta Utara, 14430 Indonesia \\ Email: pattysimon@ymail.com
}

\begin{abstract}
Analysis of Water Quality based on Physico-chemical Parameters in Bolaang Mongondow Waters, North Sulawesi
\end{abstract}

Bolaang Mongondow waters in North Sulawesi is very important estuarine waters due to both land and ocean influenced oceanographic conditions. Observations of water quality along Bolaang Mongondow coast-line have been carried out in February 2019. This study aim to analyze the quality of sea water based on the physico-chemical parameters of Bolaang Mongondow waters. The parameters observed includes temperature, the clarity of water, salinity, dissolved oxygen (DO), phosphate, nitrate and PH. Samplings were conducted using Nansen tube on the surface layer (0-1 $\mathrm{m}$ ) and near the bottom (>15 m) on 9 research stations along Bolaang Mongondow coast-line. Measurements of temperature, salinity, brightness and $\mathrm{pH}$ are carried out in situ. Dissolved oxygen was measured via electrochemical method using AZ 8563 DO meter. Phosphate and nitrate were analyzed according to the light transmission method by using the 'Nicolet Evolution 100' spectrophotometer. The results obtained are water temperature ranging from 28.6-29.3 ${ }^{\circ} \mathrm{C}$; salinity 28.0-32.5 \% \%; water clarity of 7.0-14.5 m; pH 7.36-7.80; dissolved oxygen 4.83-6.41 ppm; phosphate $0,005-0,0230 \mathrm{mg} / \mathrm{l}$ and nitrate $0,005-0,0090 \mathrm{mg} / \mathrm{l}$. The statistical analysis using t-test showed that phosphate and dissolved oxygen in the water surface and close to the bottom of water were significantly different (t-hit>t-tab). The calculated index polvion calculation shows that the waters of Bolaang Mongondow ranged between unpolluted and lightly polluted. Variations in temperature, water clarity, salinity, dissolved oxygen, phosphate, nitrate and $\mathrm{pH}$ obtained in this study are still adequate to sustain marine life.

Keywords: Oceanography, Seawater, Salinity

\begin{abstract}
Abstrak
Perairan Bolaang Mongondow, Sulawesi Utara adalah perairan estuari yang mempunyai peran penting karena kondisi oseanografi dipengaruhi oleh aktivitas yang di berasal dari daratan maupun laut. Pengamatan kualitas air laut di wilayah perairan Bolaang Mongondow telah dilaksanakan pada bulan Februari 2019. Tujuan dari penelitian adalah untuk mengukur kualitas perairan berdasarkan parameter fisik-kimia air laut. Parameter yang diteliti meliputi suhu, salinitas, kecerahan, oksigen terlarut, fosfat, nitrat, dan $\mathrm{pH}$. Sampel air laut diambil menggunakan tabung Nansen pada lapisan kedalaman permukaan air $(0-1 \mathrm{~m})$ dan perairan yang mendekati dasar $(>15 \mathrm{~m})$ pada 9 stasiun penelitian. Pengukuran suhu, kecerahan, salinitas dan $\mathrm{pH}$ dilakukan secara langsung di lapangan. Pengukuran oksigen terlarut, fosfat dan nitrat dilakukan di laboratorium dengan metode elektrokimia menggunakan DO meter AZ-8563. Untuk oksigen terlarut dan metode transmisi cahaya dengan alat spektrofotometer 'Nicolet Evolution 100' untuk fosfat dan nitrat. Hasil yang diperoleh yaitu suhu air berkisar antara 28,6-29,3 ${ }^{\circ} \mathrm{C}$; salinitas 28,0-32,5\% \% ; kecerahan 7,0-14,5 m; pH 7,36-7,80; oksigen terlarut 4,83-6,41 ppm; fosfat 0,005-0,0230 mg/l dan nitrat 0,005-0,0090 mg/l. Oksigen terlarut dan fosfat yang terdapat di permukaan dan dekat dasar laut menunjukkan adanya perbedaan nyata (t-hit>t-tab) dengan menggunakan analisis uji t. Berdasarkan nilai indeks pencemaran menunjukkan perairan Bolaang Mongondow berada dalam kondisi baik hingga tercemar ringan.
\end{abstract}


Variasi suhu, kecerahan, salinitas, oksigen terlarut, fosfat, nitrat dan PH yang diperoleh masih berada dalam kisaran angka normal untuk kehidupan biota laut.

Kata kunci: Oseanografi, Perairan laut, Salinitas

\section{PENDAHULUAN}

Perairan Bolaang Mongondow, Sulawesi Utara merupakan perairan pantai dan estuarin. Nelayan setempat menjadikan perairan ini sebagai daerah untuk menangkap ikan. Hal ini karena perairan ini merupakan salah satu wilayah dengan kondisi subur dengan konsentrasi berbagai jenis ikan.Perairan pantai Bolaang Mongondow tergolong daerah yang produktif karena adanya proses kombinasi pada air laut dan air payau yang bersumber dari beberapa sungai di darat, sehingga menyebabkan perairan ini memiliki tingkat kesuburan yang baik, berdasarkan analisis dasar sektor yang dilaksanakan di Kabupaten Bolaang Mongondow oleh Sambuari et al., (2015)dinyatakan bahwa sektor di basis Kabupaten ini memiliki potensi perikanan yang cukup baik. Kondisi oseanografi perairan Kabupaten ini umumnya dipengaruhi oleh bawaan air yang bersumber dari sungaisungai di daratan Bolaang Mongondow.

Ditinjau dari letak geografisnya, perairan Bolaang Mongondow relatif terbuka, berhadapan langsung dengan laut Sulawesi sehingga mudah terpengaruh oleh massa air dari laut tersebut dan kegiatan di daratan. Struktur ekosistem yang beraneka ragam (kompleks), model aliran arus laut, gelombang surut-pasangnya air laut yang berubah-ubah, aliran sungai yang menuju ke arah laut maupun berbagai macam aktivitas masyarakat di daerah ini seperti perikanan, pariwisata dan pelabuhan laut yang tidak terkontrol akan mengakibatkan perubahan kualitas perairan. Seperti halnya polusi bahan bakar dari transportasi laut seperti perahu dan kapal nelayan, sampah dari penduduk di sekitar pinggiran pantai serta jenis-jenis bahan organik dan anorganik yang masuk ke laut melalui aliran sungai dapat mencemari lingkungan perairan.

Banyak daerah perairan, yang dulunya adalah daerah perikanan yang cukup melimpah dengan biota laut kemudian menjadi tidak melimpah dengan ikan lagi, hal ini bukan hanya diakibatkann oleh adanya pencemaran, namun juga dipengaruhi oleh faktor seperti perubahan lain seperti fisik dan kimia perairan. Perubahan komponen fisika dan kimia tidak hanya memberikan pengaruh penurunan kualitas perairan namun selain itu bisa menyebabkan bagian dasar perairan mengalami penurunan sehingga berpengaruh terhadap kehidupan biota laut di dalamnya sebagaimana yang dijelaskan dalam penelitian Mudatsir (2007) bahwa faktor-faktor seperti fisika dan kimia yang adalah bagian faktor abiotik serta faktor biotik, adalah beberapa kondisi yang mempengaruhi kualitas air dan organisme yang ada dalam komunitas air. Berdasarkan faktor-faktor yang sudah disebutkan dengan maka dilakukan suatu penelitian tentang kajian kualitas perairan Bolaang Mongondow. Penelitian dilakukan bertujuan untuk mengukur dan menganalisis kualitas dari perairan di Kabupaten Bolaang Mongondow menggunakan parameter fisika dan kimia perairan laut.

\section{MATERI DAN METODE}

Penelitian ini dilaksanakan di wilayah perairan Bolaang Mongondow pada Februari 2019. Parameter fisika-kimia yang dianalisis di antaranya yaitu: suhu, kecerahan, salinitas, fosfat, oksigen terlarut (DO), nitrat dan $\mathrm{pH}$. Setiap stasiun penelitian ditentukan posisinya menggunakan alat GPS Garmin handportable Map 60 CSx seperti yang bisa diamati dalam Gambar 1.

Tabung nansen digunakan untuk pengambilan sampel air laut pada lapisan permukaan air laut dan posisi pengambilan selanjutnya pada dekat dasar laut. Berdasarkan sampel yang diperoleh dilakukan pengukuran kadar nitrat dan fosfat dengan alat yang digunakan yaitu spektrofotometer UV VIS dengan satuan mg/l secara ex situ (di 
laboratorium WLN-Manado). Pengukuran parameter yang lainnya meliputi suhu, kecerahan, salinitas, $\mathrm{pH}$ dan oksigen terlarut dilakukan secara in situ menggunakan beberapa alat ukur. Termometer GMK-910T digunakan untuk mengukur suhu air laut, salinitas diukur menggunakan alat Atago hand refractometer, untuk mengukur kecerahan air digunakan alat sechi disk, $\mathrm{pH}$ air air laut diukur dengan pH meter AZ 8682 dan oksigen terlarut menggunakan DO meter AZ 8563. Semua metode analisis berdasarkan pada petunjuk metode standar dalam pengukuran air dan cemaran (APHA, AWWA, WEF, 2005).

Software SURFER 8 dan ArcGis 10.2 digunakan untuk olah data sehingga dapat disajikan dalam bentuk peta sebaran. sedangkan analisis statistik untuk menentukan beda nyata dilakukan dengan menggunakan perangkat lunak SPSS 16. Indeks pencemaran (PI) ditentukan berdasarkan data hasil pengukuran yang dilakukan di titik-titik stasiun penelitian dan dari hasil analisis laboratorium. Data yang diperoleh kemudian secara deskriptif dinilai berdasarkan kriteria indeks pencemaran, disesuaikan dengan standar baku mutu kualitas air untuk biota laut menurut KepmenLH Nomor 51 Tahun 2004 yang selanjurnya dilakukan perhitungan mutu statusnya menggunakan metode Indeks Pencemaran air yaitu:

$$
P I_{j}=\sqrt{\frac{\left(C_{i} / L_{i j}\right)_{M}^{2}+\left(C_{i} / L_{i j}\right)_{R}^{2}}{2}}
$$

Keterangan : $\mathrm{C}_{\mathrm{i}}=$ Kosentrasi parameter kualitas air hasil survei; $L_{i j}=$ Kosentrasi parameter kualitas air dalam baku mutu peruntukan (j); $\mathrm{Pl}_{\mathrm{j}}=$ Indeks pencemaran bagi peruntukan (j); $\left(C_{i} / L_{i j}\right)_{M}=$ Nilai $C_{i} / L_{i j}$ Maksimum; $\left(C_{i} / L_{i j}\right)_{R}=$ Nilai $C_{i} / L_{i j}$ Rata-rata;

Kriteria status mutu air laut berdasarkan nilai Indeks Pencemaran sebagai berikut : $0 \leq \mathrm{Plj} \leq 1,0$ : memenuhi baku mutu (kondisi baik); $1,0 \leq \mathrm{Plj} \leq 5,0$ : tercemar ringan; $5,0 \leq \mathrm{Plj} \leq 10$ : tercemar sedang; $\mathrm{Pl}_{\mathrm{j}} \geq 10$ : tercemar berat

\section{HASIL DAN PEMBAHASAN}

Hasil analisis kualitas air yang yang diantarannya adalah salinitas, suhu, kecerahan, oksigen terlarut, fosfat, nitrat, dan dan PH di perairan Bolaang Mongondow disajikan dalam Tabel 1. Hasil penelitian berdasarkan data yang diamati menunjukkan bahwa suhu di perairan di Bolaang Mongondow berkisar antara $28,6-29,3 \circ \mathrm{C}$, hal ini sejalan dengan data suhu air rata-rata di perairan laut Indonesia menurut Susilo et al., (2015) yang berkisar antara $27-32{ }^{\circ} \mathrm{C}$ dengan kelimpahan ikan paling banyak yang ditangkap biasanya terjadi pada permukaan air laut dengan yang berkisar antara $25,74-35^{\circ}$ $\mathrm{C}$ dan suhu rata-rata $31.37^{\circ} \mathrm{C}$. Kisaran suhu dalam hasil penelitian masih dalam batas

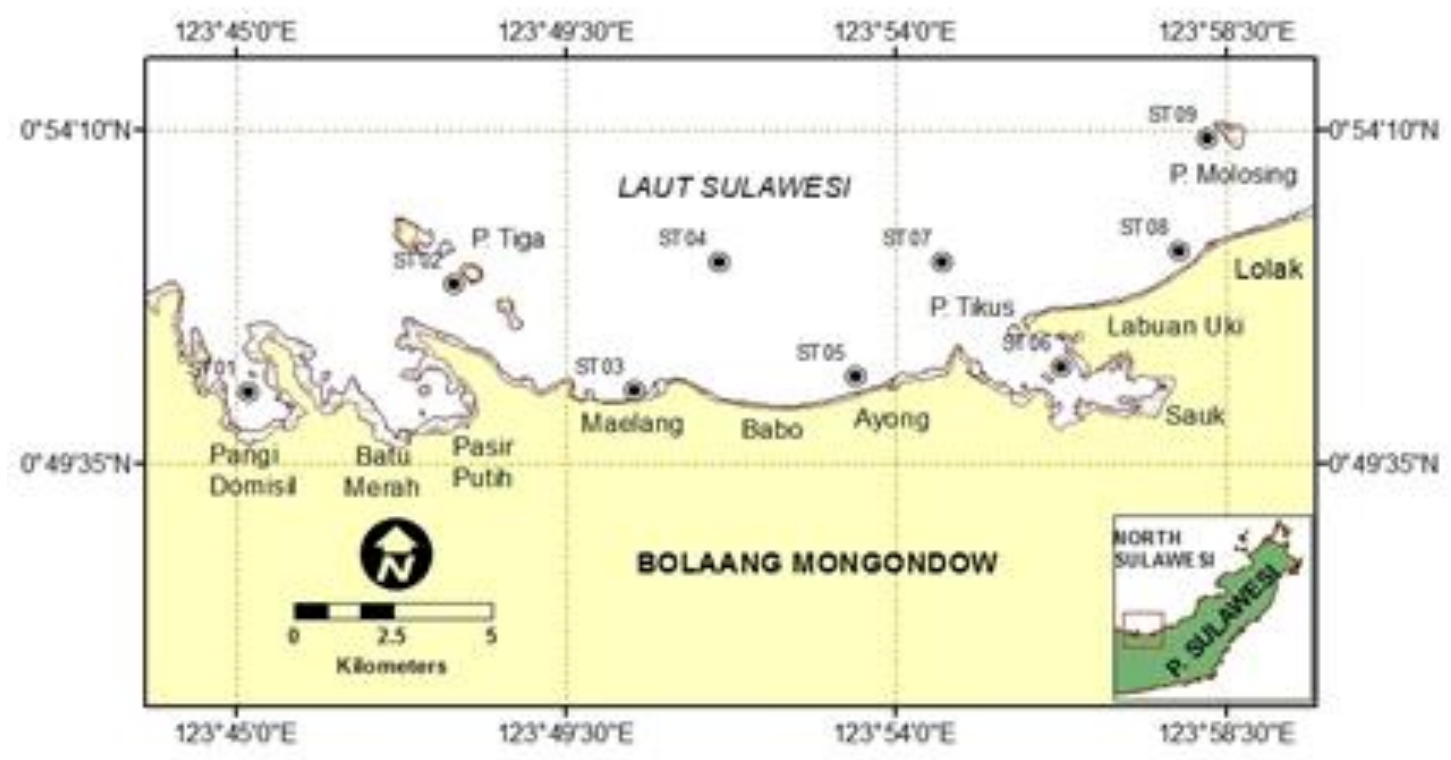

Gambar 1. Lokasi penelitian 
optimal suhu air laut yaitu $28-32{ }^{\circ} \mathrm{C}$ sehingga masih dikategorikan cocok untuk keberlangsungan hidup biota laut. Selain suhu optimal 28-32 C menurut Kepmen LH No 51 (2004) untuk kehidupan biota laut masih diperbolehkan terjadi perubahan suhu air laut sampai dengan $<2 \circ \mathrm{C}$.

Beberapa hasil kajian mengungkapkan perubahan nilai suhu di perairan mengindikasikan bahwa perubahan tersebut dipengaruhi faktor luar yang diantara lain adalah angin dan cuaca. Selain itu, suhu air juga dipengaruhi terutama oleh kondisi iklim, atmosfir, dan sinar matahari yang masuk ke laut karena beberapa faktor seperti pergeseran spasial (geografis), temporal, dan dinamika arus laut (Supangat et al., 2015). Suhu air paling tinggi biasanya terdapat pada perairan yang arahnya mendekati darat (Gambar 2). Hal ini bisa terjadi karena adanya pergerakann massa air yang mengalami gesekan dan penurunan volume massa air yang menghasilkan energi panas dari aliran sungai air tawar dari daratan yang menuju permukaan laut, hal ini bisa mempengaruhi perbedaan antara suhu air dekat darat dan perairan dilepas pantai (Najamuddin, 2017).

Tabel 1. Kisaran dan rerata parameter fisika-kima air laut di perairan Bolaang Mongondow

\begin{tabular}{cccccc}
\hline \multirow{2}{*}{ Parameter } & \multirow{2}{*}{ Baku mutu * } & \multicolumn{2}{c}{ Permukaan } & \multicolumn{2}{c}{ Dekat Dasar } \\
\cline { 3 - 6 } & & Kisaran & Rerata \pm SD & Kisaran & Rerata \pm SD \\
\hline Suhu $\left({ }^{\circ} \mathrm{C}\right)$ & $28-30$ & $28,7-29,3$ & $28,9 \pm 0,19$ & $28,6-29,1$ & $28,8 \pm 0,17$ \\
Salinitas $(\% / \%)$ & $33-34$ & $28,5-32,5$ & $30,6 \pm 1,32$ & $28,0-32,0$ & $30,3 \pm 1,37$ \\
Kecerahan $(\mathrm{m})$ & $>5$ & & $7,0-14,5$ & $(11,06 \pm 2,34)$ & \\
$\mathrm{pH}$ & $7-8,5$ & $7,45-7,78$ & $7,64 \pm 0,12$ & $7,36-7,80$ & $7,62 \pm 0,16$ \\
$\mathrm{DO}(\mathrm{mg} / \mathrm{l})$ & $>5$ & $4,85-6,41$ & $6,00 \pm 0,49$ & $4,83-6,39$ & $5,93 \pm 0,51$ \\
Fosfat $(\mathrm{mg} / \mathrm{l})$ & 0,015 & $0,005-0,0194$ & $0,0091 \pm 0,0041$ & $0,005-0,0230$ & $0,0104 \pm 0,0050$ \\
Nitrat $(\mathrm{mg} / \mathrm{l})$ & 0,008 & $0,005-0,0080$ & $0,0065 \pm 0,0011$ & $0,005-0,0090$ & $0,0069 \pm 0,0013$ \\
\hline
\end{tabular}

*) Baku mutu air laut untuk biota laut (Kepmen LH No 51 Tahun 2004).
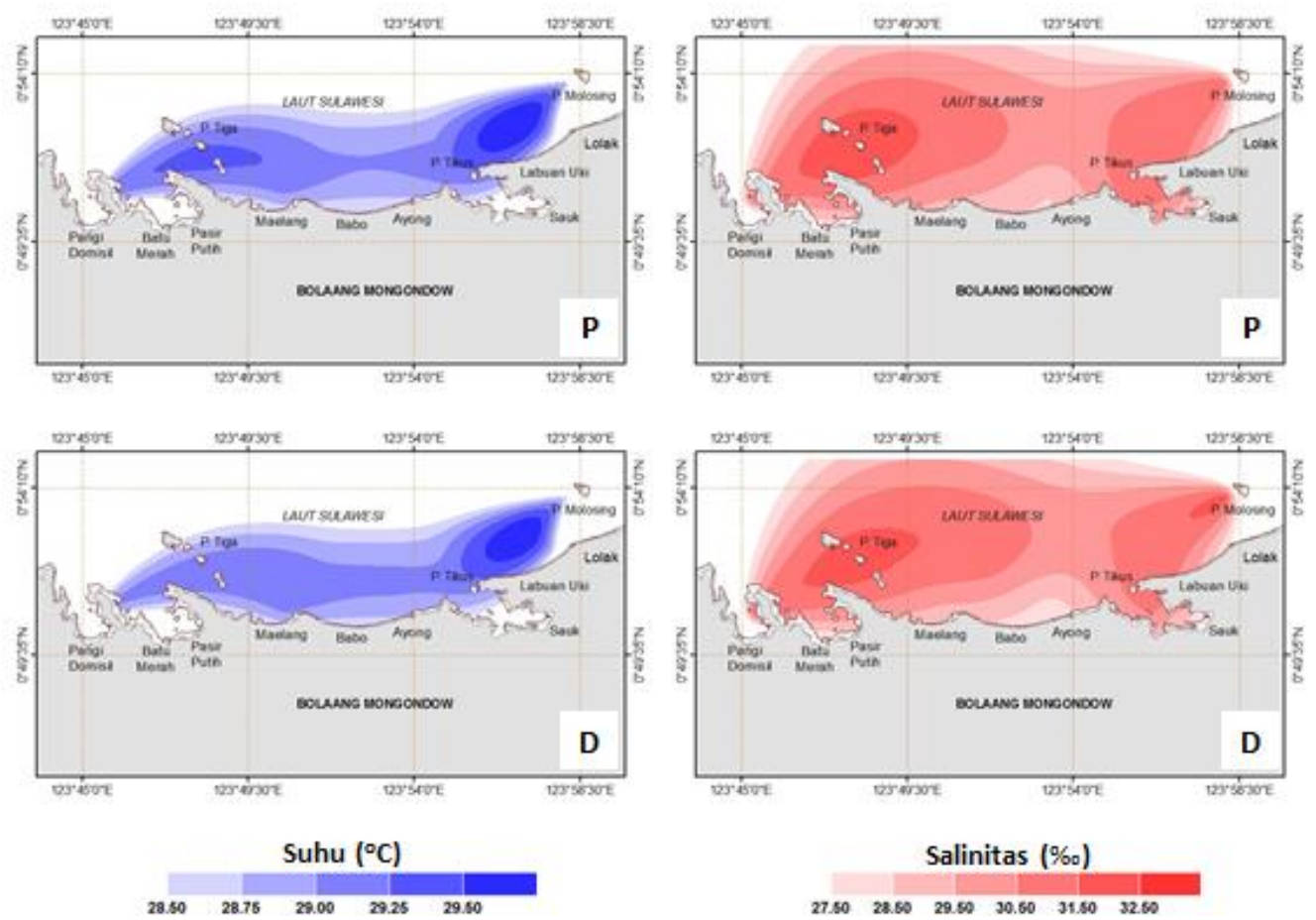

Gambar 2. Sebaran suhu air dan salinitas lapisan permukaan (P) dan dekat dasar (D) di perairan Bolaang Mongondow, Februari 2019 
Salinitas berada pada rentang antara 28,0-32,5\%, Hasil ini masih tergolong rendah karena berada dibawah batas nilai salinitas normal pada air laut dan air payau yang umumnya berada pada kisaran antara 31,034,0\% (Meirinawati dan Iskandar, 2019), namun nilai ini masih sesuai dengan standar baku mutu air laut untuk biota laut (Kepmen LH No.51/ 2004). Dari Gambar 2 terlihat salinitas $<31 \%$ mendominasi perairan, pada wilayah penyebaran ke arah laut tercatat bahwa salinitas ditemukan pada nilai tertinggi sedangkan nilai salinitas makin rendah pada sebaran wilayah yang menuju arah daratan. Rendahnya nilai salinitas di wilayah perairan dekat darat ini mengindikasikan bahwa terdapat faktor-faktor dari darat yang mempengaruhi seperti bercampurnya air tawar dengan air laut yang dibawa oleh aliran sungai. Kadar salinitas juga dapat dipengaruhi oleh beberapa faktor, diantara lain aliran sungai dan curah hujan, pola sirkulasi air, terjadinya percampuran (mixing) akibat gelombang dan pergerakan massa air yang diakibatkan oleh angin dan penguapan. Di lokasi dengan penguapan tinggi karena angin dan temperatur tinggi mengakibatkan terjadinya peningkatan pada konsentrasi salinitas. (Yu et al., 2017).

Kecerahan air laut di perairan ini menunjukkan nilai 7,0-14,5 m dengan nilai rata-rata $11,06 \mathrm{~m}$. Nilai ini masih tergolong dalam kategori baik dan sesuai untuk nilai baku mutu air biota laut yaitu > 5 meter (KepmenLH No.51/2004). Tingkat kecerahan terendah $<10 \mathrm{~m}$ dijumpai pada stasiun-stasiun berdekatan dengan muara sungai, hal ini diakibatkan karena bercampurnya bahan organik dan anorganik, partikel terlarut dan banyaknya sedimen-sedimen dari buangan sungai yang menyebabkan terjadinya kekeruhan pada air yang akhirnya menghambat penetrasi cahaya dan hasilnya adalah tingkat kecerahan air menjadi rendah. Temuan-temuan ini didukung dengan hasil penelitian Mainassy (2017) yang mendapati bahwa kecerahan sangat dipengaruhi oleh faktor limbah manusia yang pada akibatnya menyebabkan tingginya jumlah partikel yang tersuspensi dan partikel terlarut pada wilayah perairan.
Suatu perairan laut dikategorikan baik apabila derajat keasamannya $(\mathrm{pH}>7))$ atau bersifat basa. Berdasarkan data, $\mathrm{pH}$ air laut perairan Bolaang Mongondow berkisar antara 7,36-7,80, yang artinya nilai tersebut digolongkan dalam kategori rendah khususnya jika dibandingkan dengan nilai $\mathrm{pH}$ perairan yang normal. Menurut Susana (2009) nilai $\mathrm{pH}$ yang masuk dalam kategori normal di perairan berada pada rentang 8,0 - 8,3 dan nilai $\mathrm{pH}$ yang berbeda dengan standar merupakan indikator terganggunya perairan tersebut (Sudirman, 2014). Beberapa faktor yang bisa mengakibatkan rendahnya nilai $\mathrm{pH}$ di perairan ini bisa berupa faktor oksidasi, curah hujan, pengaruh dari daratan seperti massa air dari sekitar muara sungai. Dari Gambar 3, terlihat perbedaan nilai pH air laut di setiap stasiun pengamatan pada lapisan permukaan air dan perairan dekat dasar relatif sama (homogen), hal ini biasanya dipengaruhi oleh sifat air laut yang memiliki pH yang umumnya relatif stabil dengan kisaran nilai yang sempit, dan biasanya dipengaruhi oleh kapasitasnya sebagai buffer (penyangga) dengan pengaruh faktor seperti kondisi $\mathrm{CO}_{2}$ pada permukaan air laut dan adanya serta garam-garam bikarbonat dan karbonat yang terkandung di dalamnya (Jiang et al., 2019).

Sifat air laut lebih merujuk pada kondisi yang basa (alkali), namun dengan kondisi tersebut makluk hidup dan organisme laut masih mampu untuk beradaptasi apabila terjadinya perubahan $\mathrm{pH}$ laut karena daya adaptasi yang cukup luas (Udi et. al., 2011). Berdasarkan standar baku mutu air laut, nilai $\mathrm{pH}$ perairan di Bolaang Mongondow masih memenuhi standar aman untuk kehidupan biota laut, yaitu pada kondisi $\mathrm{pH}$ berkisar antara 7-8,5 yang sesuai dengan standar yang ditentukan oleh KepmenLH No.51/2004. Beberapa penelitian lain seperti Susana (2005) menetapkan nilai $\mathrm{pH}$ antara 6.5-8,5 masih memenuhi kriteria dan masih cukup ideal untuk kehidupan biota laut. Sedangkan menurut Edward dan Tarigan (2003) kondisi perairan dengan $\mathrm{pH}$ 7-8.5 masih berpotensi dalam kegiatan rekreasi/ pariwista dan budidaya sumber daya laut yang bernilai ekonomis penting, sedangkan untuk nilai $\mathrm{pH}$ yang normal untuk kelangsungan ekosistem seperti terumbu berada pada kisaran 6-9. 
Umumnya kadar DO nilainya bisa berubah-ubah, yaitu pada kisaran antara 6 14 ppm. Nilai DO di permukaan air laut termasuk dalam kadar tercemar ringan apabilai kadarnya adalah $5 \mathrm{mg} / \mathrm{l}$ dan masuk dalam kategori tercemar berat apabila kadarnya $<2.0$ mg/ I (Andara et al., 2014 : DePasquale et al., 2015). Berdasarkan hasil pengukuran didapati bahwa kadar DO permukaan di perairan ini berada pada kisaran 4,85-6,41 ppm dan oksigen terlarut pada wilayah perairan dekat dasar berada pada kisaran 4,83-6,39 ppm. Kisaran nilai oksigen permukaan lebih rendah dibandingkan dengan nilai oksigen di lapisan permukaan laut pada umumnya. Kadar oksigen terlarut di perairan ini masih dalam ambang batas untuk kehidupan biota laut (KepmenLH No.51/2004) dan masih tergolong tercemar ringan yaitu 4,5-6,4 ppm (Andara et al., 2014). Rendahnya kadar DO perairan dekat pantai diduga dipengaruhi oleh tingginya kekeruhan air dan aktivitas mikro organisme yang semakin meningkat dalam menguraikan zat organik menjadi anorganik yang membutuhkan oksigen terlarut. Bahan buangan organik yang semakin banyak di dalam air, menyebabkan semakin sedikitnya sisa kandungan oksigen yang terlarut di dalamnya. Kosentrasi oksigen dengan kadar tertinggi lebih dari 6 ppm mendominasi perairan, sedangkan konsentrasi oksigen dengan kadar terendah sebarannya mendekat ke arah pantai (Gambar 3).

Hasil penelitian menunjukkan bahwa rata-rata DO permukaan lebih tinggi dari DO dekat dasar, ini dikarenakan oksigen yang berasal dari atmosfir mengalami proses pelarutan pada lapisan permukaan. Kadar DO pada lapisan permukaan akan lebih tinggi, dikarenakan terjadinya proses difusi yang terjadi antara air dan udara bebas dan adanya proses fotosintesis, semakin bertambahnya kedalaman mengakibatkan proses fotosintesis tidak efektif (Hamzah dan Trenggono, 2014). Hal ini diperkuat dengan hasil analisis statistik menggunakan uji-† yang menunjukkan bahwa terdapat perbedaan ( $t$ hit > t-tab) antara oksigen di lapisan permukaan dengan oksigen dekat dasar (Tabel 2).

Kadar fosfat dari hasil penelitian ini menunjukkan perbedaan yang cukup signifikan, konsentrasi fosfat dekat dasar perairan lebih tinggi dibandingkan dengan di lapisan permukaan. Dari hasil analisis statistik
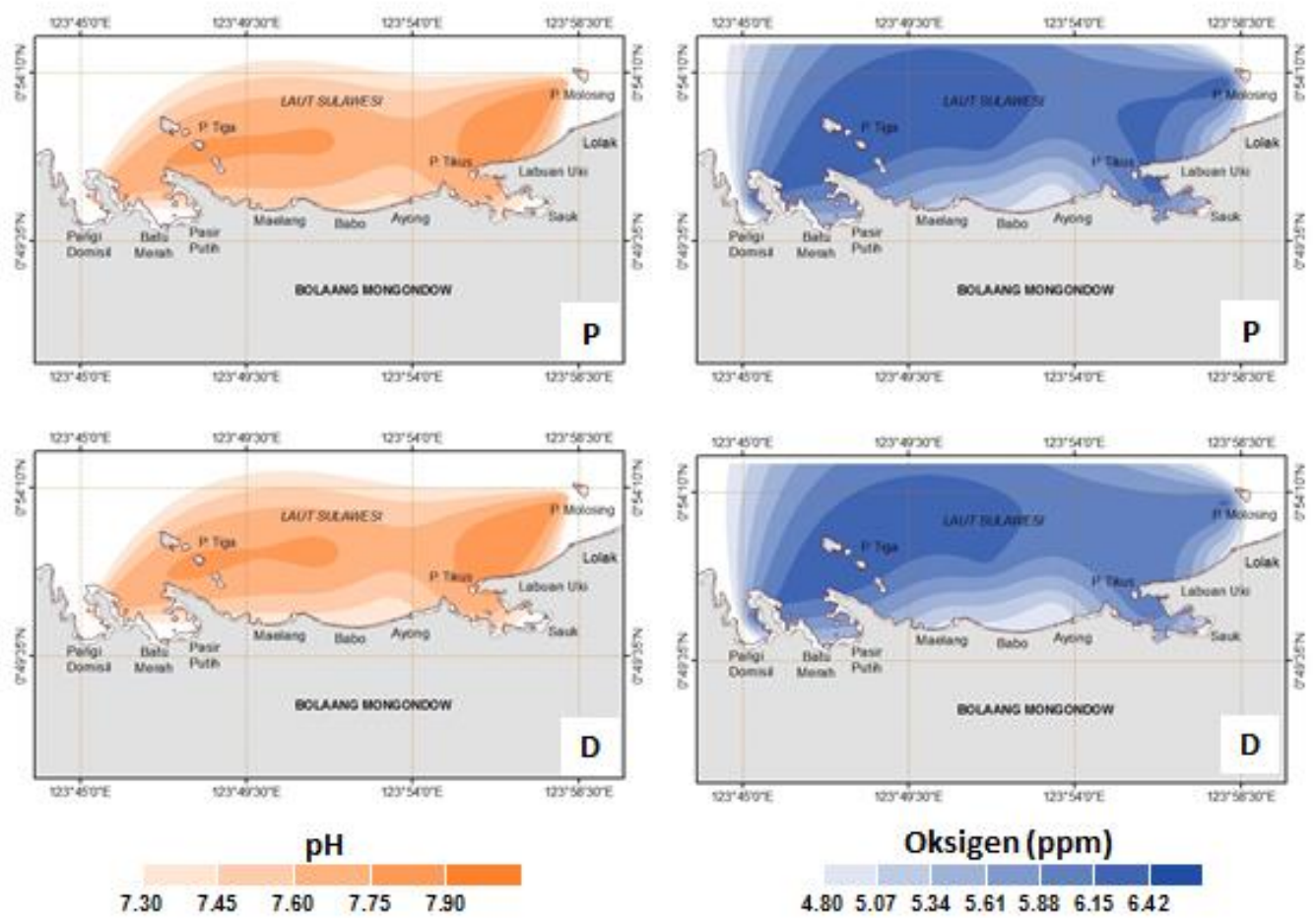

Gambar 3. Sebaran pH dan DO permukaan lapisan air (P) dan dekat dasar (D) 
menunjukkan adanya perbedaan (t-hit $>$ ttab) antara kadar fosfat dekat dasar dan lapisan permukaan (Tabel 2). Hal ini dikarenakan dasar perairan umumnya memiliki zat hara yang melimpah, baik yang berasal dari senyawa organik yang berasal dari jasad flora dan fauna maupun dekomposisi sedimen (Edward dan Tarigan, 2003). Rendahnya kadar fosfat di permukaan diduga disebabkan oleh aktivitas fitoplankton yang cukup intensif. Kondisi ini sesuai dengan pendapat Hamzah dan Trengano (2014) bahwa oksigen di lapisan bawah laut digunakan untuk dekomposisi bahan organik. Dekompisis ini memberikan efek adanya regenerasi nutrien. Reminalisasi nitrat dan fosfat dimana pada lapisan dalam, konsentrasi kedua nutrient tersebut lebih tinggi disbandingkan pada lapisan termoklin (permukaan). Rata-rata kadar fosfat lapisan permukaan 0,0091 $\pm 0,0041 \mathrm{mg} / \mathrm{l}$ dan kadar fosfat di dekat dasar nilai rata-ratanya $0,0104 \pm 0,0050 \mathrm{mg} / \mathrm{l}$. Nilai-nilai konsentrasi ini masih masih berada dalam ambang batas yang dipersyaratkan, baku mutu konsentrasi fosfat yang layak untuk kehidupan biota laut adalah sebesar $0,015 \mathrm{mg} / \mathrm{l}$ (KepmenLH No.51/2004). Nilai fosfat sebesar 2,8 ug.at/l atau setara dengan $0,087 \mathrm{mg} / \mathrm{l}$ sebagai batas air yang tidak tercemar atau berdasarkan penelitian terkini tingkat maksimum fosfat yang disarankan untuk perairan adalah 0,1 $\mathrm{mg} / \mathrm{l}$ (Anhwange, 2012).

Kosentrasi fosfat dengan kadar terendah mendominasi perairan menuju ke arah laut, sedangkan fosfat dengan kadar tertinggi sebarannya mendekat ke arah pantai (Gambar 4). Kadar fosfat tertinggi ditemukan pada stasiun 06 di teluk (Labuan Uki) yang diduga disebabkan tingginya difusi fosfat dari sedimen. Sedimen merupakan tempat penyimpanan utama fosfor dalam siklus yang terjadi di laut. Selain itu, berbagai aktivitas masyarakat di dalam teluk Labuan Uki salah satunya perkenomian seperti perikanan, transportasi laut, galangan kapal dan sebagainya, bisa dipastikan bahwa sumber utama penyumbang fosfat ke dalam teluk adalah limbah domestik masyarakat. Sebagaimana dijelaskan dalam hasil penelitian South dan Nazir (2016) bahwa detergen yang berada di pasaran umumnya mengandung fosfat yang sulit terurai di lingkungan.

Hasil perhitungan nitrat berkisar antara 0,005-0,0090 mg/l, nilai ini masih di bawah ambang batas. Rata-rata kadar nitrat di lapisan permukaan 0,0065 $\pm 0,0011 \mathrm{mg} / \mathrm{l}$ lebih rendah dibandingkan dekat dasar yaitu $0,0069 \pm 0,0013 \mathrm{mg} / \mathrm{l}$. kadar nitrat yang rendah di lapisan permukaan dikarenakan di lapisan permukaan nitrat lebih banyak dimanfaatkan oleh fitoplankton. Dan konsentrasi nitrat yang tinggi di dekat dasar juga dipengaruhi oleh sedimen. Kosentrasi nitrat permukaan maupun dekat dasar dengan kadar tertinggi sebarannya mendekat ke arah pantai dan kadar terendah penyebarannya menjauh menuju ke arah laut (Gambar 4). Kondisi ini diperkuat oleh hasil penelitian Patty (2015) yang menyatakan bahwa konsentrasi nitrat lebih tinggi di dekat dasar perairan dibanding dengan di lapisan permukaan, sedangkan untuk sebaran horizontal kadar nitrat semakin tinggi menuju kearah pantai. Bila ditinjau dari kadar nitrat yang merupakan salah satu indikator kesuburan, maka kosentrasi nitrat di perairan ini masih dalam batas aman kesuburan suatu perairan. Disebutkan bahwa baku mutu konsentrasi nitrat yang layak untuk kehidupan biota laut adalah 0,008 mg/l (Kepmen LH No 51 Tahun 2004).

Tabel 2. Analisis uji- $\dagger$ terhadap suhu, salinitas, pH, oksigen, fosfat dan nitrat

\begin{tabular}{lccccc}
\hline \multirow{2}{*}{ Parameter } & \multirow{2}{*}{ Sig. (2-tailed) } & \multirow{2}{*}{ t-hit } & \multirow{2}{*}{ df } & \multicolumn{2}{c}{ t-tab } \\
\cline { 5 - 6 } & & & & $5 \%$ & $1 \%$ \\
\hline Suhu permukaan-dekat dasar & 0,512 & 0,894 & 8 & 2,306 & 3,355 \\
Salinitas permukaan-dekat dasar & 0,341 & 0,686 & 8 & 2,306 & 3,355 \\
pH permukaan-dekat dasar & 0,006 & 3,012 & 8 & 2,306 & 3,355 \\
Oksigen permukaan-dekat dasar & 0,009 & $3,459^{*}$ & 8 & 2,306 & 3,355 \\
Fosfat permukaan-dekat dasar & 0,173 & 1,496 & 8 & 2,306 & 3,355 \\
Nitrat permukaan-dekat dasar & & & & & 3,355 \\
\hline
\end{tabular}

Keterangan: * berbeda nyata 

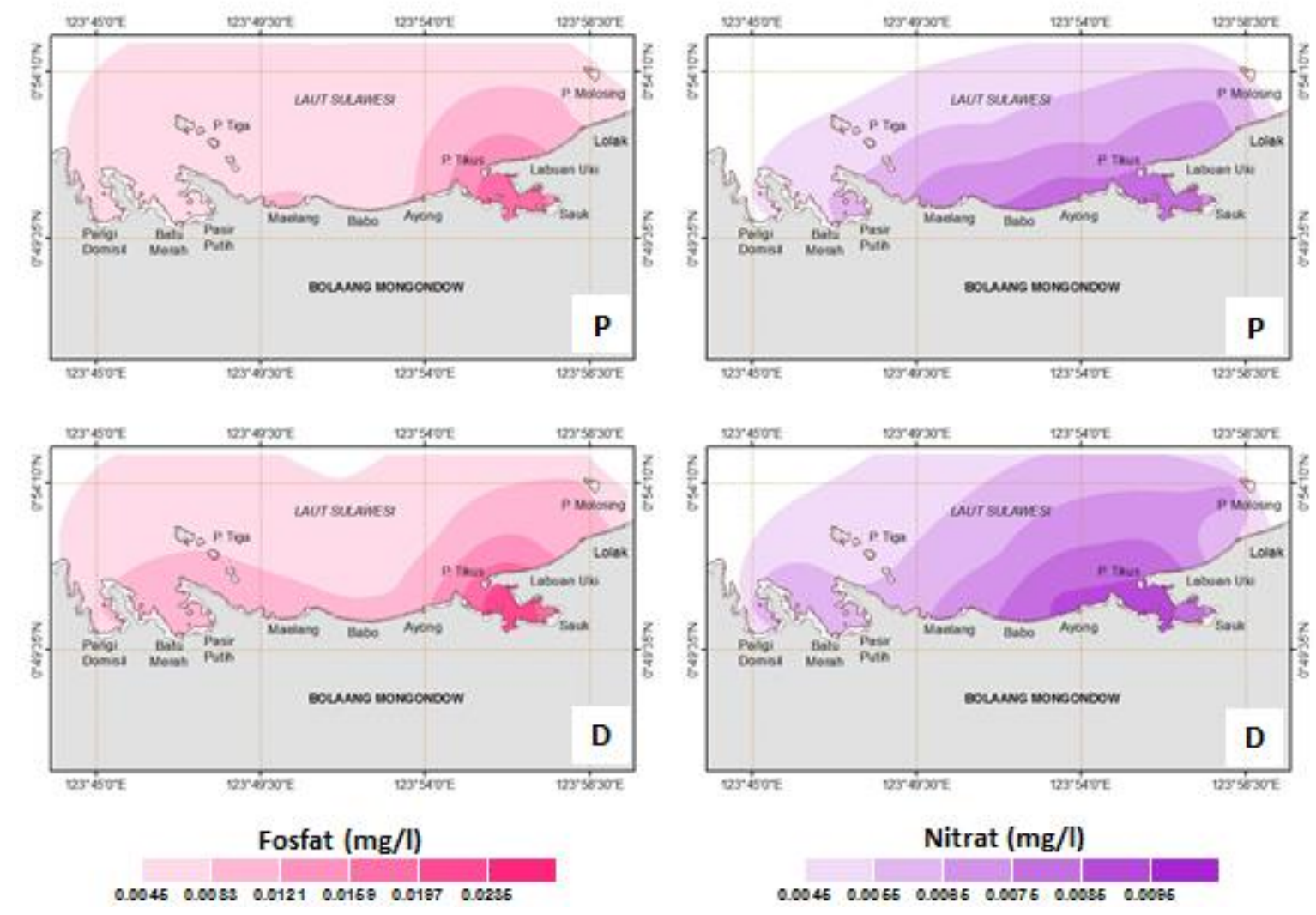

Nitrat $(\mathrm{mg} / \mathrm{l})$

$0.0045 \quad 0.0065 \quad 0.0086 \quad 0.0076 \quad 0.0086 \quad 0.0085$

Gambar 4. Sebaran fosfat dan nitrat permukaan (P) dan dekat dasar (D) di perairan Bolaang Mongondow

Tabel 3. Nilai indeks pencemaran air laut di perairan Bolaang Mongondow

\begin{tabular}{ccccccccc}
\hline \multirow{3}{*}{ St. } & \multicolumn{9}{c}{ Permukaan $(0 \mathrm{~m})$} & \multicolumn{4}{c}{ Dekat Dasar } \\
\cline { 2 - 8 } & $\begin{array}{c}\text { Ci/Lij } \\
\text { Max }\end{array}$ & $\begin{array}{c}\text { Ri/Lij } \\
\text { Rerata }\end{array}$ & Plj & Status & $\begin{array}{c}\text { Ci/Lij } \\
\text { Max }\end{array}$ & $\begin{array}{c}\text { Ci/Lij } \\
\text { Rerata }\end{array}$ & Plj & Status \\
\hline 1 & 0.68 & -0.15 & 0.49 & Kondisi baik & 0.81 & -0.02 & 0.57 & Kondisi baik \\
2 & 0.63 & -0.08 & 0.45 & Kondisi baik & 0.63 & -0.13 & 0.45 & Kondisi baik \\
3 & 0.93 & -0.01 & 0.65 & Kondisi baik & 0.85 & -0.02 & 0.60 & Kondisi baik \\
4 & 0.71 & -0.13 & 0.51 & Kondisi baik & 0.79 & -0.11 & 0.56 & Kondisi baik \\
5 & 0.99 & 0.05 & 0.70 & Kondisi baik & 1.18 & 0.08 & 0.84 & Kondisi baik \\
6 & 1.56 & 0.05 & 1.10 & Tercemar ringan & 1.93 & 0.14 & 1.37 & Tercemar ringan \\
7 & 0.79 & -0.09 & 0.56 & Kondisi baik & 0.95 & -0.08 & 0.67 & Kondisi baik \\
8 & 0.85 & -0.02 & 0.60 & Kondisi baik & 0.70 & -0.04 & 0.50 & Kondisi baik \\
9 & 0.76 & -0.14 & 0.55 & Kondisi baik & 0.86 & -0.12 & 0.62 & Kondisi baik \\
\hline
\end{tabular}

Mutu kualitas air dilihat dari nilai indeks pencemaran. Hasil penelitian menunjukkan mutu perairan Bolaang Mongondow berada pada kondisi baik sampai tercemar ringan, nilai indeks pencemaran sebesar 0,45-1,37 (Tabel 2). Di mana nilai ini masih rendah bila dibandingkan dengan hasil penelitian yang dilakukan oleh Patty et al. (2019) yang melakukan penghitungan nilai indeks pencemaran dengan metode yang sama pada perairan Teluk Manado yaitu 0,34-2,33.

Dari Tabel 3, terlihat stasiun 6 tercemar ringan, indeks pencemaran tertinggi 1,37 ditemukan di dekat dasar dan lapisan permukaan dengan indeks pencemaran 1,10. 
Tingginya pencemaran ini diduga karena lokasi sampling berdekatan dengan sungai dan pelabuhan yang merupakan penyumbang limbah pada perairan. Parameter lingkungan yang memiliki konsentrasi tertinggi melebihi baku mutu adalah nitrat dan fosfat. Kedua parameter ini perlu diperhatikan karena mengandung nutrien dan zat hara dimana jika berada dalam konsentrasi tertentu dapat menyebabkan eutrofikasi yang berbahaya bagi biota yang ada di perairan tersebut (Hamuna et al., 2018).

\section{KESIMPULAN}

Perairan Bolaang Mongondow memiliki kualitas perairan yang masih tergolong baik sehingga masih memungkinkan untuk kehidupan biota laut. Variasi nilai kecerahan, suhu, salinitas, $\mathrm{pH}$, oksigen terlarut, fosfat, dan nitrat masih berada pada kisaran normal untuk perairan pantai. Agar kualitas perairan tidak mengalami perubahan ke arah yang tidak diinginkan, maka diharapkan dapat dilakukan penelitian yang berkesinambungan di perairan ini.

\section{DAFTAR PUSTAKA}

APHA, AWWA, WEF, 2005. Standard method for the examination of water and wastewater, edition 21: 4-153.

Andara, D.R., Haerudin. \& Suryanto, A. 2014. Kandungan Total Padatan Tersuspensi, Serta Indeks Pencemaran Sungai Klampiasan di Kawasan Industri Candi Semarang. Management of Aquatic Resources. 3(3):177-187.

Anhwange, B.A., Agbaji, E.B., \& Gimba, E.C. 2012. Impact Assessment of Human Activities and Seasonal Variation on River Benue, within Makurdi Metropolis. Journal of Science and Technology. 2: 248-254. doi : 10.4236/jwarp.2017.91007

DePasquale, E., Baumann, H., \& Gobler, C.J. 2015. Vulnerability of early life stage Northwest Atlantic forage fish to ocean acidification and low oxygen. Marine Ecology Progress Series. 523:145-156. doi : 10.3354/meps 11142.

Edward \& Tarigan, Z. 2003. Pemantauan kondisi hidrologi diperairan Raha P. Muna, Sulawesi Tenggara Dalam Kaitannya dengan Kondisi Terumbu Karang. Makara Sains, 7(2):73-82. doi: 10.7454/mss.v7i2.330 Hamuna, B., Tanjung, R.H, Suwito, Maury, K. \& Alianto. 2018. Kajian Kualitas Air Laut dan Indeks Parameter Fisika-Kimia Di Perairan Distrik Depapre, Jayapura. Jurnal IImu Lingkungan, 16(1):35-43. doi: 10.14710/jil. 16.1.35-43.

Hamzah, F. \& Trenggono, M. 2014. Oksigen Terlarut di Selat Lombok. Jurnal Kelautan Nasional 9(1): 21-35. doi : 10.15578/jkn. v9i1.6199

Jiang, L.Q., Carter, B.R., Feely, R.A., Lauvset, S.K. \& Olsen, A., 2019. Surface ocean pH and buffer capacity: past, present and future. Scientific reports, 9(1):1-11. doi : 10.1038/s41598-019-55039-4.

Mainassy, M.C. 2017. Pengaruh Parameter Fisika dan Kimia terhadap Kehadiran Ikan Lompa (Thryssa baelama Forsskal) di Perairan Pantai Apui Kabupaten Maluku Tengah. Jurnal Perikanan Universitas Gadjah Mada 19(2):61-66. Doi : $10.22146 /$ jfs. 28346

Meirinawati, H. \& Iskandar M.R. 2019. Karakter Fisika dan Kimia Perairan di Laut JawaAmbang Dekawang. Oseanologi dan Limnologi di Indonesia 4(1): 41-52. Doi : 10.14203/oldi.2019.v4i1.140

Menteri Negara KLH, 2004. Keputusan Menteri Negara Lingkungan Hidup No.51 Tahun 2004 Tentang Baku Mutu Air Laut Untuk Biota Laut. Jakarta, hal. 32.

Mudatsir. 2007. Faktor-faktor yang mempengaruhi kehidupan mikroba dalam air. Jurnal Kedokteran Syiah Kuala, $7(1): 23-29$.

Najamudin. 2017. Variasi musiman parameter fisika kimia di sekitar perairan estuaria jeneberang, Sulawesi Selatan. Prosiding Seminar Nasional KSP2K II. 1 (2):1-15.

Patty, S.I. 2015. Karakteristik Fosfat, Nitrat dan Oksigen Terlarut di Perairan Lembeh, Sulawesi Utara. Jurnal Pesisir dan Laut Tropis 2(1):1-7. doi : 10.35800/jplt.3.2.2015. 9581.

Patty, S. I., Rizqi, M.P., Rifai, H. \& Akbar, N. 2019. Kajian Kualitas Air dan Indeks Pencemaran di Teluk Manado Ditinjau Dari Parameter Fisika-Kimia Air Laut. Jurnal IImu Kelautan Kepulauan 2(2):1-13.

Sambuari, S.S., Rumate, V., \& Siwu, H. 2015. Analisis sektor basis di Kabupaten Bolaang Mongondow Utara. Jurnal Berkala IImiah 
Efisiensi 15(04): 148-159. doi : 10.13140/RG. 2.2.23002.39368

South, A.E. \& Nazir, E. 2016. Karakteristik air limbah rumah tangga (grey water) pada salah satu perumahan menengah keatas yang berada di Tangerang Selatan. Ecolab, 10(2): 80-88. doi: 10.20886/jklh. 2016.10.2.80-88.

Sudirman, N. \& Husrin, S. 2014. Status Baku Mutu Air Laut Untuk Kehidupan Biota dan indeks Pencemaran Perairan di Pesisir Cirebon Pada Musim Kemarau. Jurnal Ilmiah Perikanan dan Kelautan. 6(2):149-154. doi : 10.20473/jipk.v6i2.11300

Supangat, A., Adi, T.R., Pranowo, W.S., \& Ningsih, N.S. 2015. Predicting Movement of the Warm Pool, the Salinity Front, and the Convergence Zone in the Western and Central Part of Equatorial Pacific Using a Coupled Hydrodynamical Ecological Model. The Twelfth OMISAR Workshop on Ocean Models. 11 pp.
Susana, T. 2005. Kualitas Zat Hara Perairan Teluk Lada, Banten. Oseanologi dan Limnologi di Indonesia, 37:59-67.

Susilo, E., Islamy, F., Saputra, A.J., Hidayat, J.J., Zaky, A.R. \& Suniada, K.I. 2015. Pengaruh Dinamika Oseanografi Terhadap Hasil Tangkapan Ikan Pelagis PPN Kejawanan dari Data Satelit Oseanografi. Seminar Nasional Perikanan dan Kelautan V. Universitas Brawijaya. 299-304 pp.

Udi, P. \& Nana, S.S. 2011 . Manajemen kualitas air pada kegiatan perikanan budidaya. Departemen Kelautan dan Perikanan Direktorat Jendral Perikanan Budidaya Balai Budidaya Air Payau Takalar.

Yu, L., Jin, X., Josey, S. A., Lee, T., Kumar, A., Wen, C., \& Xue, Y. 2017. The global ocean water cycle in atmospheric reanalysis, satellite, and ocean salinity. Journal of Climate 30(10):3829-3852. doi : 10.1175/ JCLI-D-16-0479. 